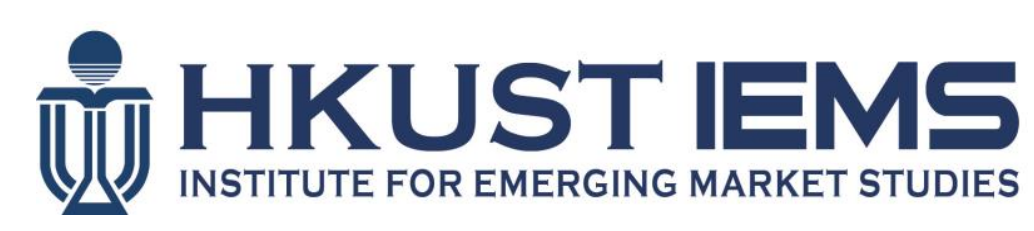

\title{
How Does Foreign Bank Entry Affect Financial Inclusion in Emerging and Developing Economies?
}

\author{
Sasidaran GOPALAN, Ramkishen S. RAJAN
}

HKUST IEMS Working Paper No. 2015-04

February 2015

\begin{abstract}
HKUST IEMS working papers are distributed for discussion and comment purposes. The views expressed in these papers are those of the authors and do not necessarily represent the views of HKUST IEMS.
\end{abstract}

More HKUST IEMS working papers are available at: http://iems.ust.hk/WP 


\title{
How Does Foreign Bank Entry Affect Financial Inclusion in Emerging and Developing Economies?
}

Sasidaran GOPALAN, Ramkishen S. RAJAN

HKUST IEMS Working Paper No. 2015-04

February 2015

\begin{abstract}
An important dimension of the effects of foreign bank entry on financial sector development relates to that of financial inclusion. Despite its policy significance, the empirical literature offers little evidence on the impact of bank competition generally or foreign bank entry specifically on financial inclusion. This paper examines the relationship between foreign bank entry and financial inclusion for a panel of 57 emerging and developing economies over the period 2004-2009. The empirical findings suggest that foreign banks have a positive impact in furthering financial inclusion, though the relationship turns negative when foreign bank entry is followed by greater banking concentration.
\end{abstract}

\section{Author's contact information}

Sasidaran Gopalan

Institute for Emerging Market Studies (IEMS) and Institute for Advanced Study (IAS)

The Hong Kong University of Science and Technology

E: gopalan@ust.hk

Ramkishen S. Rajan

School of Policy, Government and International Affairs (SPGIA)

George Mason University 


\title{
How DoES Foreign Bank ENTRY AFFECT FinanCIAL INCLUSION IN EMERGING AND DEVELOPING ECONOMIES?
}

\author{
Sasidaran Gopalan* and Ramkishen S. Rajan ${ }^{++}$
}

(This Version: February 4, 2015)

\begin{abstract}
An important dimension of the effects of foreign bank entry on financial sector development relates to that of financial inclusion. Despite its policy significance, the empirical literature offers little evidence on the impact of bank competition generally or foreign bank entry specifically on financial inclusion. This paper examines the relationship between foreign bank entry and financial inclusion for a panel of 57 emerging and developing economies over the period 2004-2009. The empirical findings suggest that foreign banks have a positive impact in furthering financial inclusion, though the relationship turns negative when foreign bank entry is followed by greater banking concentration.
\end{abstract}

Keywords: Foreign Bank Entry, Financial Liberalization, Financial Inclusion, Financial Development, Banking Concentration

JEL Classification: F21, G00, G21, 016

\section{Author Details:}

*Corresponding Author: Sasidaran Gopalan is Post-Doctoral Research Fellow at the Hong Kong University of Science and Technology (HKUST) Institute for Emerging Market Studies (IEMS) and Institute for Advanced Study (IAS), Hong Kong. Email: gopalan@ust.hk

${ }^{++}$Co-Author: Ramkishen S. Rajan is Professor of International Economic Policy at School of Policy, Government and International Affairs (SPGIA), George Mason University and Visiting Professor, Lee Kuan Yew School of Public Policy (LKY-SPP), National University of Singapore. 


\section{Introduction}

Does foreign bank entry contribute to financial inclusion in emerging and developing economies (EMDEs)? The impact of foreign banks on financial sector development has generally tended to focus on financial sector deepening relating to the liquidity and development of the banking sector as well as bond and equity markets (Levine, 1996; Chinn and Ito, 2006; Baltagi et al., 2009; and Calderon and Kubota, 2009) However, the other crucial dimension of financial sector development, especially from the perspective of EMDEs, involves making finance more inclusive for all households and firms in an economy. Financial inclusion can be said to encompass the process of broadening the accessibility of financial services for households and firms. In other words, it relates to the issue of providing and enabling the firms and households in an economy with access to the formal credit market. ${ }^{1}$

Since banks are the main providers of financial services in EMDEs, the focus of financial inclusion can be more narrowly thought of as banking sector "outreach", i.e. the degree to which the banking sector is able to meet the needs of a large segment of the population. Since the 1990s many EMDEs have been liberalizing their banking sectors and have allowed for greater foreign participation. The question of how foreign banks affect financial inclusion therefore assumes policy significance. The limited literature on this subject has thus far focused on whether foreign banks promote provision of physical points of access to financial services or facilitate greater use of those services by larger segments

\footnotetext{
${ }^{1}$ While provision of credit is usually channeled through the banking system in a country, it need not be the case always. In several EMDEs, even post offices play a significant role in catering to the needs of smaller households and firms by playing the core role of banks in an economy, by accepting deposits and making loans. For a discussion on the role for postal networks in expanding access to financial services, see World Bank (2005).
} 
of the population. These studies also point out concerns that the entry of foreign banks could be negatively associated with banking sector outreach owing to the tendency of foreign banks to cater to a smaller segment of the population (Beck and Martinez Peria, 2010 and references cited within). Further, it has also been noted that weak competition policy in some countries has resulted in a concentrated financial sector which has blunted the incentives for foreign banks to promote financial inclusion (Ellis, 2007).

While the policy debate about the role of foreign bank entry and financial inclusion appears to be contentious, there is very little systematic empirical analysis of the concerned issues. The existing set of empirical studies neither appears to factor in various determinants of financial inclusion nor offers any insight of changes over time owing to the cross-sectional nature of data employed in the literature.

This paper aims to advance the literature on financial inclusion by empirically testing the impact of foreign bank entry on banking sector outreach. We use broad indicators of financial inclusion in a panel framework for 57 EMDEs over 2004 to 2009. Additionally, considering the importance of the implications of banking concentration after financial liberalization in EMDEs, this paper is also specifically interested in testing how banking concentration and foreign bank entry jointly influence financial inclusion in EMDEs.

The remainder of the paper is structured as follows. Section 2 begins by examining the literature on financial inclusion. Section 3 details some of the definitional and measurement issues relating to financial inclusion. The data and model for the empirics in the paper are outlined in Section 4. The results are discussed in Section 5, along with 
robustness checks. Section 6 concludes this paper with a brief discussion of policy implications of the empirical findings.

\section{Review of Literature}

An inclusive financial system is considered to be desirable because it enhances both economic efficiency and welfare by providing opportunities for large segments of the population to adopt safe and secure saving practices, as well as facilitating the use of a range of financial services (Sarma and Pais, 2008). Ensuring broad financial services outreach is also important to ensure that the relatively poorer households or small entrepreneurs and small and medium-sized enterprises (SMEs) with inadequate collateral and insufficient credit histories are not left out of the formal credit market. Such financial exclusion could occur because of financial market imperfections such as information asymmetry or high transaction costs or lack of inadequate legal infrastructure to enforce contracts. The credit constraints that arise as a result make it difficult for the poorer households or small entrepreneurs to finance high-return investments, reducing the efficiency of resource allocation in an economy and eventually negatively impacting economic growth and poverty alleviation (Beck et al. 2007).

The literature on foreign bank entry and financial inclusion can be broadly divided into two strands, though the number of studies in each strand as well as their scope is rather limited. The first strand focuses on financial inclusion as measured by indicators of banking sector outreach. Using cross-sectional data for 2003-04 for 18 low income countries, Detragiache et al. (2008) find a general negative correlation between different measures of banking sector outreach and foreign bank participation. Similar results have been reported by Beck et al. (2007) for a different sample of countries involving 99 
countries for 2003-04. In a related paper and a fairly recent case study on Mexico, Beck and Martinez Peria (2010) use more detailed disaggregated data on the behavior of the number or share of municipalities where foreign banks are present. They find that greater foreign bank presence is associated with a decline in the number of branches, loans, and deposit accounts.

Another strand of the literature deals with the micro dimension which focuses on the 'real' impact of foreign banks on firms' and households' access to credit. This strand of literature assesses the lending patterns of foreign banks to different classes of borrowers. A long-standing debate in the literature on foreign bank entry concerns the so-called "cherrypicking" behavior of foreign banks by which they have the tendency to attract the financially transparent clients - firms or households - catering only to a smaller relatively risk-free segment of the population. This behavior arises from the existence of information asymmetry in the lender-borrower relationship. The resultant high costs of investing in lending relationships, particularly with small and opaque borrowers, may in turn lead to a reduction in the credit access for those borrowers (firms or households) (Clarke et al. 2006; Beck and Brown, 2014; Gormley, 2010).

While there has been a great deal of theoretical literature modelling the "cherrypicking" behavior of foreign banks, the corresponding empirical literature is limited (owing largely to demanding data requirements) and ambiguous at best. On the one hand, a few empirical papers find support for the view that foreign banks tend to be "fickle lenders" to opaque borrowers, though much of this evidence is limited to a few country-cases. ${ }^{2}$ On the other hand, a recent emerging literature seems to be challenging this notion of foreign

\footnotetext{
${ }^{2}$ For example, see Mian (2006) for the case of Pakistan and Gormley (2010) for the case of India.
} 
banks shying away from lending to opaque borrowers (particularly the SMEs) and posits that they are actively tapping the SME market even in countries with severe informational problems by resorting to alternative lending technologies (see De la Torre et al., 2010). ${ }^{3}$

While there is some evidence of improved access to credit for SMEs as a result of foreign bank entry, this does not appear to extend to households, and large segments of the population often still appear to have very limited access to formal financial services (Ellis, 2007).

\section{Definitions and Measurement Issues}

\subsection{Definitions}

How does one define financial inclusion? One of the simplest working definitions of financial inclusion - as defined by Amidzic et al. (2014) is that financial inclusion refers to "an economic state where individuals and firms are not denied access to basic financial services based on motivations other than efficiency criteria" (p.5). ${ }^{4}$ As the World Bank's Global Financial Development Report (2014) notes, such a definition of financial inclusion is paradoxically defined in terms of financial exclusion. Financial exclusion is broadly classified into two categories -- voluntary and involuntary exclusion. This in turn underlines the need to distinguishing between two concepts of financial inclusion: (a) access to financial services which provide the enabling environment to use financial services; and (b) the actual use of financial services (World Bank, 2014).

\footnotetext{
${ }^{3}$ This literature emphasizes the need to move beyond relationship lending based assessments in order to understand the lending behavior of foreign banks to such borrowers.

${ }^{4}$ This definition is based on World Bank (2014).
} 
On the one hand, voluntary exclusion refers to the segment of the population that chooses not to use financial services on a voluntary basis, either because they do not need those services or because their culture or religion does not permit them to utilize such services. ${ }^{5}$ On the other hand, economic agents could be involuntarily excluded from use of financial services, this being referred to as "involuntary exclusion." Involuntary exclusion consists of the individuals and firms who are denied financial services as a result of government failures or market imperfections, which necessitate corrective policy action.

While the above taxonomy is useful to understand the various conceptual intricacies in defining financial inclusion, from a measurement standpoint the concept of financial inclusion can be understood through its multiple dimensions. As the literature points out, financial inclusion comprises three main dimensions, namely the outreach, usage, and quality of financial services (Amidzic et al. 2014; Beck and Martinez Peria, 2007).

\subsection{Measurement}

The outreach dimension refers to the (physical) ability to easily reach a point of service. For instance, data from the World Bank's Global Financial Inclusion Index ('Findex') survey $^{6}$ reveals that of the 2.5 billion individuals excluded from financial systems globally, about 20 percent cite the distance to a point of financial service as the prime reason for not having an account with a formal financial institution, which is considered one of the indicators of financial inclusion. Thus, the shortage of physical points of financial services

\footnotetext{
5 This type of exclusion is not a direct consequence of market failure though and may not be very interesting from a macroeconomic perspective (Amidzic et al. 2014 and World Bank, 2014).

${ }^{6}$ The Global Financial Inclusion (Global Findex) Database, built by the World Bank, measures how adults in about 148 economies manage their finances. The indicators use survey data from household interviews globally for the year 2011 and include over 40 indicators related to ownership of accounts, information about payments, savings and borrowings etc.
} 
appears to be a significant factor in excluding a segment of population from accessing financial services. This in turn points to the need for policies to enhance accessibility of financial services through greater provision of physical points of access.

The literature suggests some proxies that effectively capture the outreach dimension of financial inclusion. The first set relate to Automatic Teller Machines (ATMs), scaled either by demography (adjusted for population) or geography (adjusted for geographic size) and the others relate to the number of bank branches scaled in a similar fashion. The literature interprets higher branch and ATM intensity in demographic and geographic terms as indicative of greater access to financial services by households and enterprises. The measurement of financial inclusion around the world can thus be understood using density indicators, such as bank branches or ATMs. ${ }^{7}$

The second dimension concerns the usage dimension of financial inclusion. Some of the proxies suggested in the literature that capture the usage dimension include: Loan accounts per capita defined as number of loans per 1,000 people; Loan-income ratio defined as average size of loans to GDP per capita; Deposit accounts per capita defined as number of deposits per 1,000 people; and Deposit-income ratio defined as average size of deposits to GDP per capita. Of these four proxies, consistent data appears to be available on a panel basis for the number of deposit accounts, defined as the reported number of deposit account holders at commercial banks and other resident banks functioning as commercial banks.

\footnotetext{
${ }^{7}$ Relevant data are compiled by surveying financial service providers and much of this provider side information on financial inclusion is now collected as part of the IMF's Financial Access Survey.
} 
The third dimension - quality dimension - measures the extent to which financial services address the needs of the consumers. As Amidzic et al. (2014) note, indicators capturing the quality dimension of financial inclusion are in turn implicit in sub-categories that include institutional variables such as financial literacy, legal requirements, the cost of usage of financial services and the like. Note that consistent panel data on the various quality dimensions of financial inclusion are not available. This constrains the focus of our empirical analysis to only the outreach and usage dimensions.

Table 1 lists and defines the four indicators or proxies of financial inclusion that we will employ in this paper for our empirical analysis.

\section{[Table 1 about here]}

In addition, Figures 1 to 3 provide a snapshot view of the relationship between the various suggested proxies of financial inclusion. Figure 1 maps the relationship between the two popular outreach indicators of financial inclusion -- ATMs and bank branches. In Figures 2 and 3, we show the relationship between different measures of "access to" and an indicator measuring "use of" financial services (number of depositor bank accounts). As Figure 1 suggests, there is a very close degree of correspondence between the two indicators, which is not necessarily the case when we compare "access to" and "use of" indicators as shown in Figures 2 and 3, a point also emphasized by World Bank (2014).

\section{[Insert Figures 1-3 here]}

\section{Data and Empirical Model}

As noted in Table 1, financial inclusion can be typically measured using user-side or provider-side indicators. User-side indicators available from the global financial inclusion 
index database are cross-sectional in nature and given that we are interested also in the time-series dimension, for our panel estimation the focus of our empirics will mainly be on provider-side indicators of financial inclusion which broadly capture physical outreach.

To that end we use the demographic penetration indicator - Automated Teller Machines (ATMs) per capita, i.e. scaled by adult population per 100,000 adults - as the main variable measuring the physical outreach dimension. Physical distance to points of financial service tends to be an important barrier to financial inclusion (World Bank, 2014; Amidzic et al., 2014).

Constraints such as inability to provide physical access points for delivery of financial services reveals important information about the accessibility of large segments of population to financial services. Viewed from the perspective of foreign banks, ATMs are much more cost effective and require the least amount of investment commitment relative to establishing bank branches or allowing deposit-taking functions. Hence using ATMs instead of bank branches as the preferred proxy would appear more intuitive to examine the role of foreign bank presence on financial inclusion. However, we also use a series of other proxies listed in Table 1 as part of our robustness measures. ${ }^{8}$ Data are compiled from both the IMF's Financial Access Survey (FAS) as well as World Bank's World Development Indicators (WDI) dataset (See Annex Table A2 for more details).

The panel data which we use for our empirical analysis is constructed for 57 EMDEs over the period 2004-2009. Annex table A1 provides the complete list of countries used in

\footnotetext{
8 We also use ATM density - the number of ATMs rescaled by land mass, i.e. number of ATMs per $1,000 \mathrm{~km}^{2}$ as an alternative dependent variable.
} 
our empirical estimation..$^{9}$ Before we proceed with our formal estimation, we map the relationship between the various financial inclusion indicators and foreign bank entry in our sample in Figures 4 to 6. A simple visual inspection appears to show no evidence of any discernible relationship, though Figure 4 tends to show a negative relationship between foreign bank entry and financial inclusion as proxied by number of deposit accounts per capita, corresponding with the findings for Mexico by Beck and Martinz Peria (2010). In similar vein, Figure 5 appears to show a slight positive relationship between bank branches and foreign bank entry with ATMs (Figure 6) appearing to exhibit no meaningful relationship. Overall, simple visual plots do not offer much informal indication about the nature of the relationship between foreign bank entry and various measures of financial inclusion. We undertake a more formal empirical analysis in the next section.

\section{[Insert Figures 4-6 here]}

\subsection{Empirical Model}

The basic estimating equation will be as follows:

$$
y_{i t}=\delta_{i}+\beta f b_{i t}+\boldsymbol{\gamma} \boldsymbol{X}_{i t}+u_{i t}
$$

where: $y_{i t}$ is the number of ATMs per capita (per 100,000 people) in country $i$ at time $t$

$\delta_{i}$ is the country fixed effect.

$f b_{i t}$ is the share of bank assets held by foreign banks in country $i$ at time $t$;

$\boldsymbol{X}_{i t}$ is a matrix of control variables measured at time $t$;

$u_{i t}$ is the idiosyncratic error term.

$\beta$ and $\gamma$ are the parameters to be estimated.

\footnotetext{
${ }^{9}$ It is worth noting that while we have compiled data for 57 EMDEs, the final count of countries used in the empirics may ultimately depend upon the respective model used which might in turn depend on the availability of consistent data for all explanatory variables.
} 
The parameter of interest is $\beta$ which represents the coefficient of the foreign bank share. Based on the literature, a selected set of macroeconomic, geographic, financial, social and institutional variables affecting financial inclusion in an economy are employed as controls in our model. The vector of control variables are listed below:

$\boldsymbol{X}_{i t}=\left\{\begin{array}{c}\text { GDP Per Capita, Surface area; } \\ \text { Overhead costs, Credit to Stateowned enterprises, Bank Concentration; } \\ \text { Creditor Information, Legal Rights; } \\ \text { Share of women employed in non - agricultural sector }\end{array}\right\}$

All the data sources are summarized in Annex Table A2. We offer below a brief description of the variables employed in our model along with the intuition behind the priors we hypothesize.

GDP Per Capita: measuring overall levels of economic development in the country. We expect a positive relationship between financial inclusion and countries with higher levels of development.

Surface Area: This is a proxy capturing a country's geographic size, which is a likely important determinant of financial inclusion. The greater the surface area the greater the spread of the population and higher are the costs of providing financial services. So a large surface area might lower the financial inclusion in an economy and we expect a negative relationship.

Overhead Costs: These costs are defined as operating expenses of a bank, expressed as a share of the value of all held assets. Greater the overhead costs the less likely the bank would be interested in greater outreach as it would increase its costs and hence it is likely to impede financial inclusion. 
Credit to State-Owned Enterprises: Measured as the ratio between credit by domestic money banks to the government and state-owned enterprises and GDP, this variable will positively influence financial inclusion, as a greater government control of the banking system implies that it has the potential to direct credit to specific areas prioritizing banking outreach. This is likely to result in a higher degree of financial repression which may be beneficial to financial inclusion.

Lerner Index: The Lerner Index measures market power in the banking industry by comparing output pricing and the marginal costs (markup). An increase in the Lerner index is associated with a decline in bank competition. We expect greater banking concentration in an economy to be a deterrent to financial inclusion as an oligopolistic type market structure is unlikely to have an incentive to promote banking sector outreach unless they are government owned and have a mandate to do so.

Credit Depth of Information Index: This variable captures the cost to banks of obtaining information about borrowers and we expect that higher information availability to be positively associated with financial inclusion in the economy, as it helps ease out information asymmetry in the lending-borrowing process, which in turn may reduce the costs for banks in promoting greater outreach.

Legal Rights Index: measuring the strength of legal rights in an economy that protect the rights of borrowers and lenders. We expect countries with stronger legal protection of creditors to have deeper credit markets because a reliable legal institutional backing is suggestive of transparency and credibility of any contract enforcement mechanism which reduces the risks involved. Thus, a sound legal system to enforce and honor contracts would encourage the banks to opt for greater outreach and would carry a positive sign. 
Share of Women Employed in Non-Agricultural Sector: A greater representation of women employed in the non-agricultural sector should enhance financial inclusion, as greater use of financial services is expected in more densely populated urban areas with a much higher density in retail access points and a higher degree of literacy among the female workforce.

\subsection{Methodology}

We use linear panel fixed-effects model to estimate equation (1). The rationale behind using fixed effects estimation stems from the fact that we are able to control for unobserved country-specific fixed characteristics that might affect financial inclusion. A further point to note is that our fixed-effects estimates will remain robust only if the potential source of endogeneity arises from the correlation between the time-invariant component of the error term and the regressor of interest. Hence we estimate equation (1) using a fixed-effects panel data model, incorporating country fixed-effects. ${ }^{10}$

While there is an intuitive reason to use fixed-effects, it is important to note that we ran a Hausman test to decide between fixed effects and random effects estimation (Annex Table A3). The results suggest that the assumption of absence of any correlation between the time invariant error term and the regressors is not unreasonable and hence favours the use of a generalized least squares (GLS) random effects specification for our panel regressions. However, taking into account the critique in the literature about the limited powers of the Hausman test (Beck, 2001; Cameron 2007) and the potential endogeneity concerns that could be present in estimating our model, we use fixed effects estimation as

\footnotetext{
${ }^{10}$ Considering that time fixed effects are unlikely to be important in shorter panels dealing with a time span of six years, we do not include time fixed effects in our estimation. The literature generally points out that time fixed effects for shorter time series are econometrically trivial (Beck, 2001). However, taking into account the suggestion of the referees that our model spans two years that overlap with the global financial crisis (GFC), we instead included a dummy reflecting the GFC period in our baseline specification.
} 
the preferred methodology through the paper. ${ }^{11}$ However, we also present the random effects results for our key baseline specification only as a robustness check.

\section{Empirical Results}

\subsection{Baseline Model}

We start with our baseline model as outlined in equation (1) that estimates the relationship between foreign bank entry and financial inclusion as proxied by ATMs per capita, controlling for macroeconomic, institutional and financial variables. We then proceed to examine the joint influence of foreign bank entry and bank concentration on financial inclusion.

The results of our panel estimation using fixed effects with standard errors clustered for countries are summarized in the first two columns of Table 2. While column (1) reports estimates of our baseline without foreign bank entry, column (2) presents the estimation results with the inclusion of foreign bank variable. For the purposes of comparison, columns (3) and (4) present the random effects GLS results as robustness.

\section{[Insert Table 2 about here]}

The model produces several significant variables and broadly all of them conform to our priors. GDP per capita is highly significant at the 1 percent level, consistent with our priors. Among the institutional variables, creditor information appears to be highly statistically significant in explaining financial inclusion. The credit to government owned enterprises is also highly significant at the 1 percent level, carrying a positive impact on financial inclusion as we noted earlier. It is interesting that surface area is also significant at

${ }^{11}$ We thank anonymous referees for emphasizing this point. 
the 5 percent level but appears to have the incorrect sign. We would expect to see a negative sign, as a wide geographical area captured by surface area should be a deterrent to financial inclusion. However, while this variable is statistically significant, its economic significance is quite marginal. Alternatively we used population density as an alternative control and we did not find it to be significant. Since both the variables were highly correlated, we did not use the two together in the regressions.

As the next step we add the foreign bank entry variable to examine its relationship with financial inclusion. The results are shown in Column (2) and they emphasize the robustness of the model. While most of the variables continue to be significant from our baseline without foreign bank entry, foreign bank entry per se appears to be positive and statistically significant at the 5 percent level. Note that controlling for foreign bank entry makes the overhead costs of the banks significant at the 5 percent level with a negative sign, which is what we expect from the priors in our model.

Controlling for foreign bank presence also appears to reduce the measure of financial repression proxied by credit to government owned enterprises, indicating the positive competitive effects foreign banks bring in to the economy. At the same time, note that the measure of concentration remains statistically significant, though only marginally at the 10 percent level. Legal rights also become marginally significant when controlled for foreign bank presence. Overall, most variables appear to be consistent from our previous model, with foreign bank entry strengthening some of the relationships, in accordance with our priors. The subsequent two columns (3) and (4) show the results of the random effects estimation and it is clear from the table that they are broadly comparable to those of fixed effects estimates. 
In order to understand how financial inclusion is affected by the joint influence of foreign bank entry and concentration, we re-run our baseline fixed effects model with an interaction term between the two concerned variables. The results, as shown in Column (1) in Table 3, yield interesting results that are once again consistent with our priors. While foreign bank entry continues to carry a statistically significant and positive impact on financial inclusion, the joint interaction between foreign bank entry and banking concentration not only carries a negative sign but also possesses significant explanatory power at the 5 percent level. Thus the influence of foreign bank entry and bank concentration remains highly statistically and economically significant. This result provides evidence that while foreign bank entry by itself could bring in a host of economic benefits, including the enhancement of financial inclusion, it could still impede financial inclusion if the post entry of foreign banks is followed by greater banking concentration. Another way of interpreting these results is that if greater entry of foreign banks merely transforms the market structure from a government-dominated banking system to an oligopolistic structure controlled by foreign private banks, the net impact may be detrimental to the goals of achieving enhanced financial inclusion. Column (2) produces the results of the random effects GLS estimation, which appears to be broadly consistent with our fixed effects results, adding an additional layer of robustness.

\section{[Insert Table 3 about here]}

Before we proceed to using other proxies of financial inclusion to check the robustness of results we have arrived at so far are, we re-run our baseline regression to include a time dummy representing the Global Financial Crisis (GFC) phase to see if our results are sensitive to the GFC period. The empirical results of our baseline estimation 
including GFC dummy is given in Table 4. Most importantly, note that despite the significance of GFC dummy, the significance of our main variable of interest - impact of foreign bank entry on financial inclusion - remains unaffected.

\section{[Insert Table 4 about here]}

\subsection{Robustness Checks}

We test the relationship between foreign bank entry and financial inclusion by using three other alternative indicators of financial inclusion as robustness checks, consistent with what was reported in Table 1 . It is useful to recollect that the proxies we use as robustness measures attempt to capture both dimensions of financial inclusion in terms of "access to" and "use of" financial services, in addition to testing if our results are consistent across both the demographic as well as geographic indicators.

We start with ATM density measured as ATMs per 1,000 square $\mathrm{km}$. The results of our fixed effects estimation are summarized in Table 5. We follow an exercise similar to what we did in the previous section by running our baseline without foreign bank entry (column 1), followed by its inclusion (column 2), and finally the augmented model with the interaction term between foreign bank entry and bank concentration (column 3). The results are broadly consistent with what we observed for our baseline specification. While foreign bank entry retains a positive and significant relationship with financial inclusion (column 2), its joint influence with banking concentration remains negative and significant (column 3).

[Insert Table 5 about here] 
In Table 6 we use deposit bank accounts as the proxy capturing the usage dimension of financial inclusion to if our results on foreign bank entry are still robust. In the full augmented model reported in Column 3 we find that, in addition to economic size and financial repression, foreign bank entry positively influences financial inclusion. However, the concentration relationship does not seem to hold, though the interaction term carries the appropriate negative sign, consistent with our priors and the baseline model. It is important to highlight that when we run the baseline without foreign bank entry the number of observations drops rather drastically with consistent panel data available only for 23 countries compared to 40 countries in the model using ATMs per capita (Table 2). While the variables that are significant in this model are consistent with the priors and our baseline model, it is useful to note that the significance of the overall model per se is overshadowed by the limited number of observations we are working with.

\section{[Insert Table 6 about here]}

Table 7 presents the results of the model that uses bank branches per capita (per 100,000 adults) as the proxy for financial inclusion and uses the benchmark model given in equation (1). Interestingly, as columns (1) and (2) in Table 7 show, most explanatory variables significant in our benchmark model with ATMs per capita continue to possess explanatory power in this model as well, consistent with our priors. However, when we have the augmented specification with the inclusion of the interaction term between foreign bank entry and bank concentration, we find that the model produces insignificant results. While the direction of coefficients appear to be in the right direction, conforming to our priors, the key variables are insignificant. A point worth emphasizing here -- taking a cue from the larger literature on foreign bank entry -- is that subsidiaries remain the most 
dominant organizational form of foreign bank entry into emerging market economies especially in the Latin American and Central Eastern European region (Cerutti et al., 2007). Considering that countries from these two regions constitute almost three-fourth of our sample in this paper, it is not unreasonable to expect bank branches to be insignificant in our empirical estimation relative to other indicators.

\section{[Insert Table 7 about here]}

Finally, moving beyond trying different indicators of financial inclusion, we also perform another robustness check that addresses some potential endogeneity concerns in our baseline empirical model. More specifically, considering that lagging our crucial independent variable on foreign bank entry could possibly lessen the endogeneity concerns by showing that changes in foreign bank participation preceded changes in financial inclusion (ATM coverage), we re-examine our hypotheses using regressing the different proxies of financial inclusion on lagged foreign bank entry, controlling for similar set of macro, financial and institutional variables as well as country fixed effects.

Table 8 presents these results. Scanning through the various models we find that our primary relationships of interest are still robust across different specifications, especially the lagged foreign bank entry variable and how it affects financial inclusion. We also find the interaction with concentration works for the models using ATM density and bank accounts, while it remains insignificant for the other two. Broadly, we find that the different models, in terms of the significance and direction of the coefficient of the various explanatory variables, are consistent with their counterpart models that used foreign bank entry without lags. The model that continues to perform poorly on a relative basis is the 
one which uses bank branches as the dependent variable and this reconfirm our conjectures noted earlier.

\section{[Insert Table 8 about here]}

In addition to re-estimating our baseline model with lagged foreign bank entry variable, we estimate an additional model in which we include a proxy for financial depth proxied by credit-to-GDP ratio as a regressor. The results are produced in Annex Table A4 with column 1 pertaining to the results of using ATMs per capita and column 2 giving the results of ATM density. As we can observe, the financial depth proxy is significant in the first model but not in the second, though the main variables of interest including foreign bank entry and the interaction with bank concentration being highly significant with the appropriate signs. We thus see that our results are consistent and robust to the inclusion of financial depth proxies. However, it is useful to reiterate that possible endogeneity inherent in foreign bank entry in EMDEs, which might self-select into financially developed countries, is a general problem with the larger literature itself. We have tried to undertake as many robustness tests as possible to lessen such concerns in this paper.

To summarize the various robustness checks, we find that, with the exception of models involving bank branches, the main relationship of interest involving foreign bank entry appears to be robust in how it affects financial inclusion in EMDEs. While admittedly there are differences in the performance of each model in terms of the significance of other explanatory variables, our conjectures about the how foreign banks affect financial inclusion and their joint influence with banking concentration is an important result to be highlighted. In fact the positive relationship we find on a consistent basis is also a crucial 
departure from the general conclusion emanating from the literature which generally suggests a negative nexus between foreign bank entry and financial inclusion.

\section{Conclusion and Policy Implications}

One of the important dimensions of the effect of foreign bank entry on financial sector development relates to that of financial inclusion. Specific indicators of financial inclusion capture the provision of physical points of access to financial services as well as indicators reflecting greater use of those services by larger segments of the population. The limited literature on this subject appears to suggest that entry of foreign banks could be negatively associated with banking sector outreach owing to the tendency of foreign banks to cater to a smaller segment of the population. However, the vast majority of the literature has tended to be cross-sectional in nature and has spanned limited number of countries.

In this light, this paper investigated the relationship between foreign bank presence and financial inclusion by using multiple indicators for 57 emerging and developing economies spanning 2004-2009. The empirical results using both a measure of demographic penetration (number of automatic teller machines (ATMs) rescaled by population) as well as geographical penetration (captured by ATM density rescaled by area of the country) produce consistent and significant results in favor of a positive impact of foreign bank presence on financial inclusion. This appears robust across all other indicators of financial inclusion as well.

The findings highlight that foreign bank entry likely contributes to easing of constraints such as the inability to provide physical access points for delivery of financial services which will in turn play an instrumental role in promoting financial inclusion. Specifically, since ATMs are much more cost effective and require the least amount of 
investment commitment, designing appropriate policies to facilitate the setting up of such physical points of access would likely enhance financial inclusion in EMDEs. In fact, since many basic banking transactions occur through ATMs in the advanced economies -obviating the need to go a teller to a certain degree -- policy makers in EMDEs could facilitate setting up of physical points of access through foreign bank entry.

That being said, it must be kept in mind, as emphasized by Demirguc-Kunt and Klapper (2012), physical outreach indicators may not necessarily provide the full picture of financial inclusion. This is because information concerning the actual use of those financial services from the user-side, in addition to measuring the degree of financial exclusion among women etc., is also important additional dimensions of financial inclusion that must be factored in. While the Global Financial Inclusion (Global Findex) Database has compiled several such user-side indicators, most of them are cross-sectional in nature and available only for a single year, limiting the usefulness of the data for our analysis in this paper. However, one of our indicators of financial inclusion used in the empirical analysis depositor bank accounts -- pertains to the usage dimension of financial inclusion. The model utilizing this indicator, despite its data limitations, appeared to be consistent in so far as the fundamental way in which foreign bank entry influences financial inclusion.

Finally, an important qualification to the empirical findings in this paper arises from the result on banking concentration and how the net positive impact of foreign bank entry on financial inclusion tends to be weakened when with greater banking concentration in an economy. This is important from a policy standpoint because greater foreign bank entry can possible result in increased banking concentration, as has been the case in several Central and Eastern European or Latin American countries (World Bank, 2008). Such an 
outcome is likely to be detrimental to the goals of achieving financial inclusion, as it merely transforms the market structure from a government-dominated banking system to an oligopolistic structure controlled by foreign private banks. While our empirical results are in no way attributing a causal relationship between foreign bank entry and banking concentration, the results are at least suggestive of a strong association between the two variables that impedes financial inclusion. This is also consistent with recent evidence by Bruhn et al. (2013) who point out how increased banking concentration in an economy can result in generating monopoly rents by the few large players in the market by holding on to information endowments and aggravating problems of information asymmetry that in turn deter new entry into the market. Hence, the role of the policy makers in EMDEs is to ensure that the liberalization of the domestic banking market does not lead to it becoming dominated by a few large banks that would lead to greater banking concentration. 


\section{References}

Amidzic, G., A. Massara and A. Mialou. 2014. "Assessing Countries' Financial Inclusion Standing - A New Composite Index," IMF Working Paper, 14/36.

Baltagi, B., P. Demetriades, and S.H.Law.2009. "Financial Development and Openness: Evidence from Panel Data." Journal of Development Economics, 89: 285-296.

Beck, N. 2001. "Longitudinal (Panel and Time-Series Cross-Section Data).” Summer 2001 Lecture Notes, University of California, San Diego.

Beck, T. and M. Brown. 2014. "Foreign Bank Ownership and Household Credit." Journal of Financial Intermediation, forthcoming.

Beck, T., A. Demirguc-Kunt, and M.S. Martinez Peria. 2007. "Reaching Out: Access to and Use of Banking Services Across Countries." Journal of Financial Economics 85 (1): 234-266.

Beck, T., A. and M.S. Martinez Peria. 2010. "Foreign bank participation and outreach: Evidence from Mexico," Journal of Financial Intermediation, 19:52-73.

Bruhn, M., S. Farazi, and Martin Kanz. 2013. "Bank Competition, Concentration, and Credit Reporting." World Bank Policy Research Working Paper 6442, Washington DC.

Calderon, C. and M. Kubota. 2009. "Does Financial Openness Lead to Deeper Domestic Markets?." World Bank Policy Research Working Paper 4973, Washington DC.

Cameron, A.C. 2007. "Panel Data Methods for Microeconometrics Using Stata." Prepared for West Coast Stata Users Group Meeting, University of California, Davis, October.

Cerutti, E., G. Dell'Ariccia and M.S. Martinez Peria. 2007. "How Banks Go Abroad? Branches or Subsidiaries?.” Journal of Banking and Finance, 31:1669-1692.

Chinn, M.D., and H. Ito. 2006. "What Matters for Financial Development? Capital Controls, Institutions and Interactions." Journal of Development Economics, 81:163-192.

Clarke, G., R. Cull, and M. S Martínez Pería. 2006. "Foreign Bank Participation and Access to Credit Across Firms in Developing Countries." Journal of Comparative Economics 34 (4): 774-795.

Claessens, S., and N. Van Horen. 2011. "Foreign Banks: Trends, Impact and Financial Stability." DNB Working Paper 330.

Claessens, S., N. Van Horen, T. Gurcanlar, and J. Mercado. 2008. "Foreign Bank Presence in Developing Countries 1995-2006: Data and Trends." Mimeo. 
Demirguc-Kunt, A. and L. Klapper. 2012. "Measuring Financial Inclusion: The Global Findex Database," World Bank Policy Research Working Paper 6025, Washington DC.

Detragiache, E., T. Tressel, and P. Gupta. 2008. "Foreign Banks in Poor Countries: Theory and Evidence." The Journal of Finance 63 (5): 2123-2160.

De la Torre, A., M.S. Martinez Pería, and S. L Schmukler. 2010. "Bank Involvement with SMEs: Beyond Relationship Lending." Journal of Banking \& Finance 34 (9): 2280-2293.

Ellis, K. 2007. "Is Financial Liberalisation Enough to Promote Financial Inclusion?" Overseas Development Institute Brief 82, June.

Gormley, T.A. 2010. "The Impact of Foreign Bank Entry in Emerging Markets: Evidence from India." Journal of Financial Intermediation 19 (1): 26-51.

Levine, R. 1996. "Foreign Banks, Financial Development, and Economic Growth." International Financial Markets: Harmonization Versus Competition 7: 224-254.

Mian, A., 2006. "Distance constraints: The limits of foreign lending in poor economies," Journal of Finance 61(3), 1465-1505.

Sarma, M. and J. Pais, 2008, "Financial Inclusion and Development: A Cross Country Analysis," mimeo.

World Bank. 2006. "The Role of Postal Networks in Expanding Access to Financial Services." World Bank, Volume II, Regional Studies, Washington DC.

World Bank, 2014, Global Financial Development Report 2014: Financial Inclusion, Washington, DC: World Bank. 


\section{Figures and Tables}

Figure 1: ATMs Per Capita and Bank Branches Per Capita

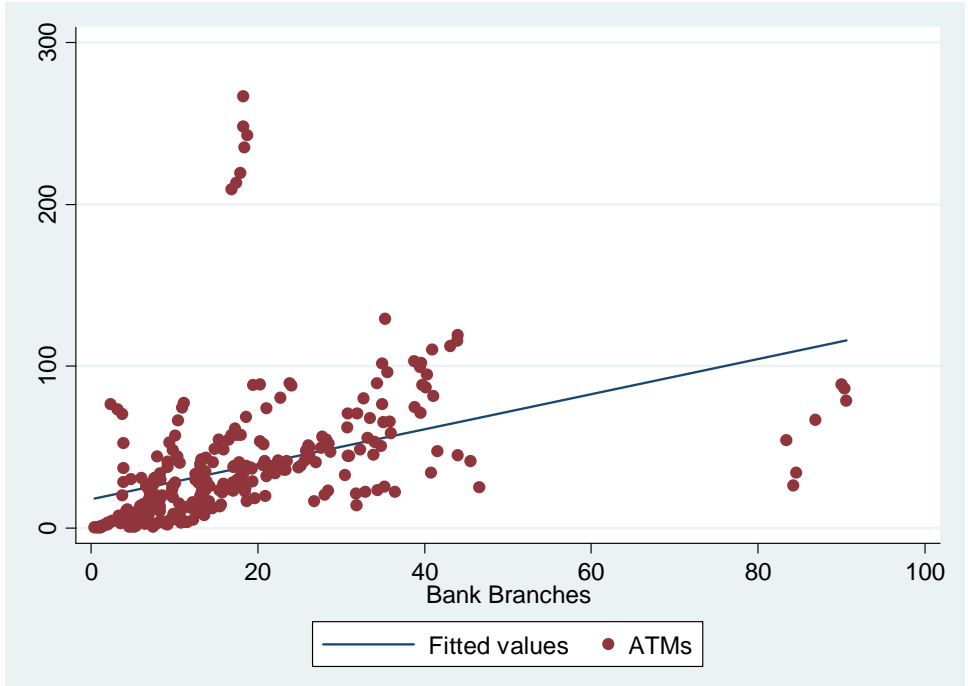

Figure 2: ATMs Per Capita and Bank Accounts Per Capita

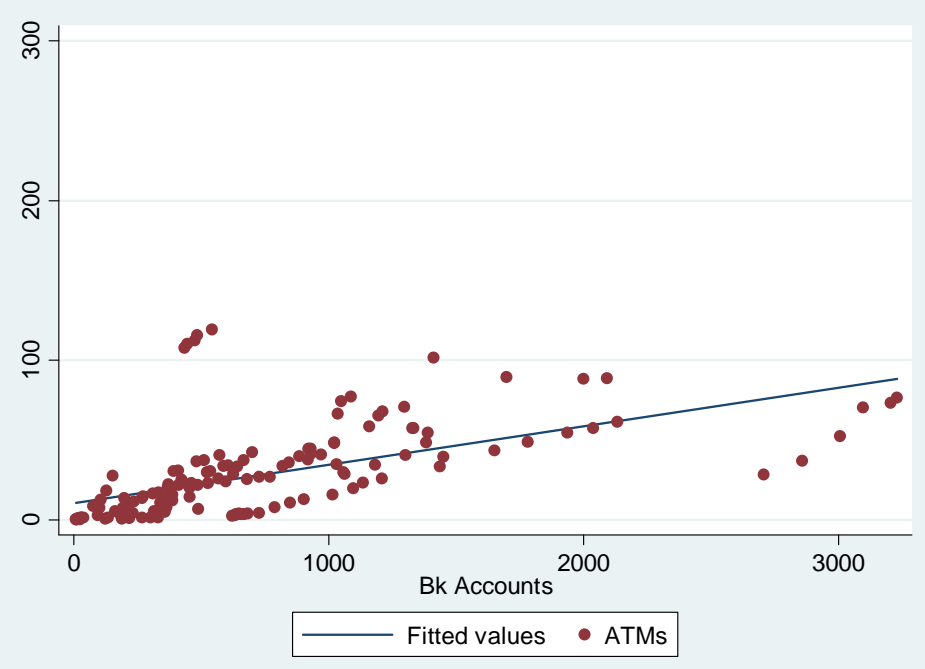


Figure 3: Bank Branches Per Capita and Bank Accounts Per Capita

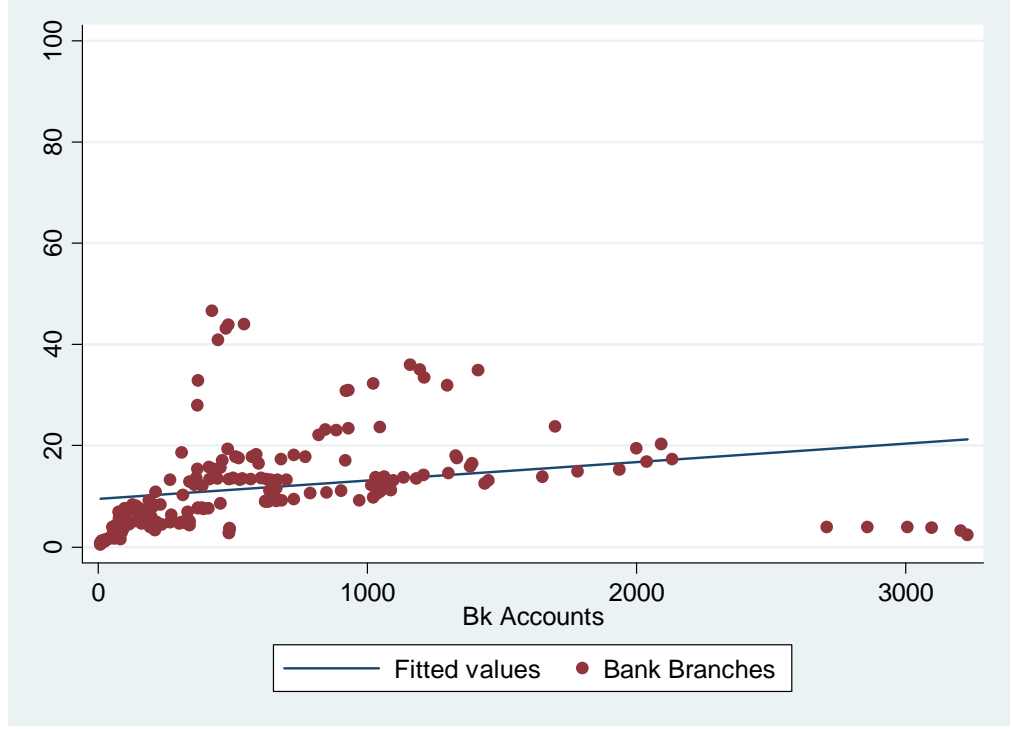

Figure 4: Bank Accounts Per Capita and Foreign Bank Entry

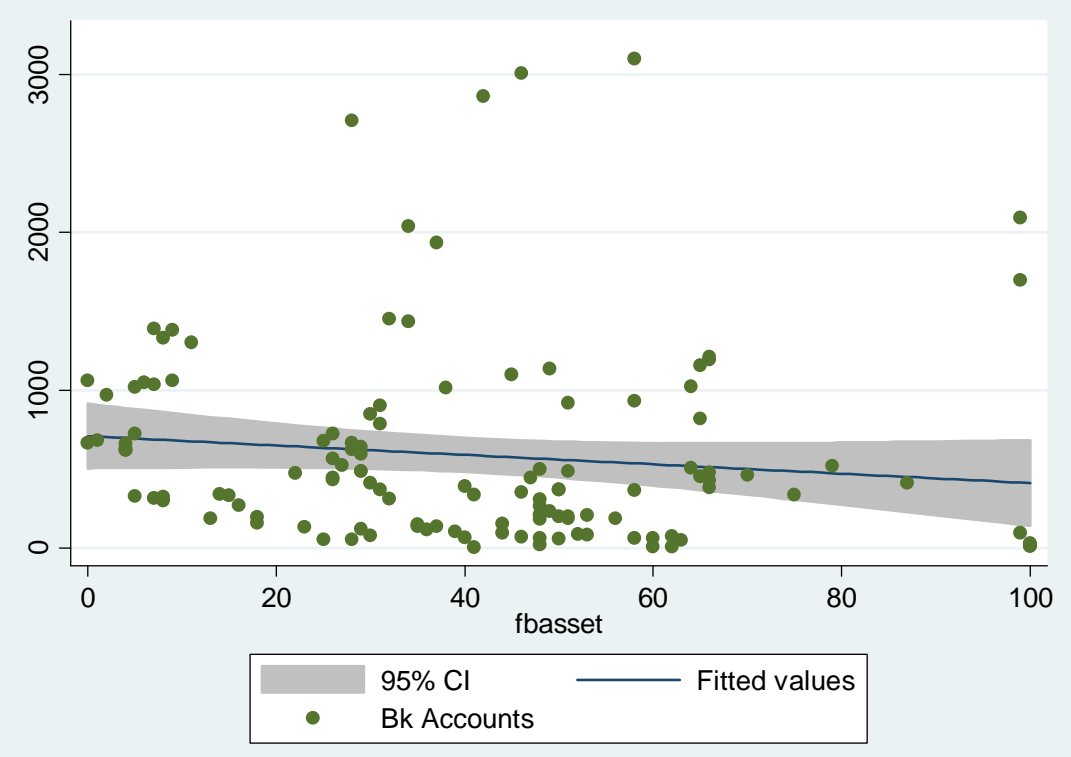


Figure 5: Bank Branches Per Capita and Foreign Bank Entry

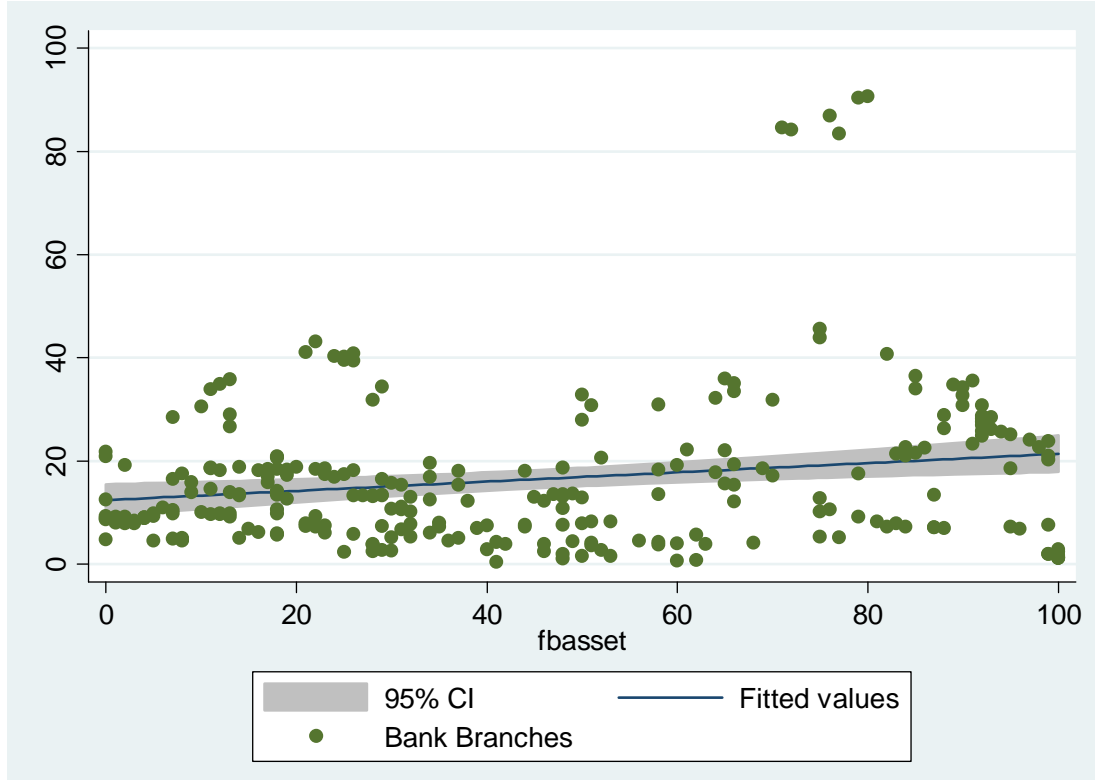

Figure 6: ATMs Per Capita and Foreign Bank Entry

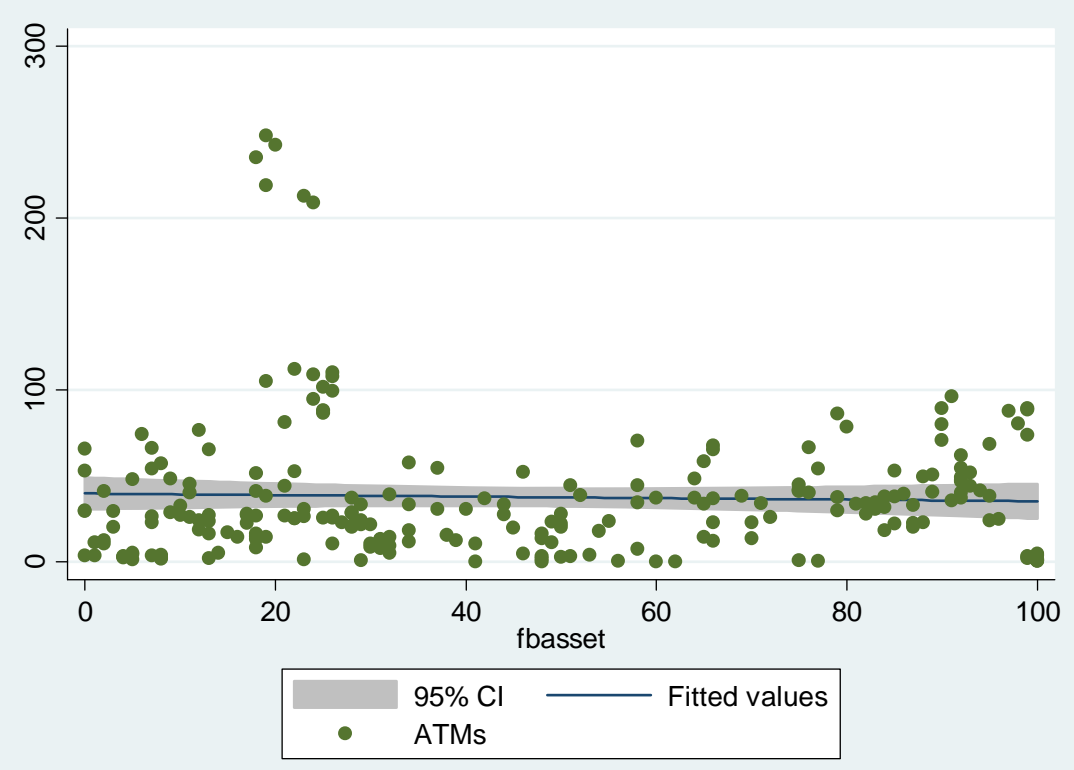


Table 1: Proxies of Financial Inclusion

\begin{tabular}{|c|c|c|c|}
\hline Variable & Definition & Feature & Source \\
\hline $\begin{array}{l}\text { Automated Teller } \\
\text { Machines (ATMs) } \\
\text { Density } \\
\text { [Geographic } \\
\text { Penetration] }\end{array}$ & $\begin{array}{l}\text { Automated teller machines are } \\
\text { computerized telecommunications } \\
\text { devices that provide clients of a financial } \\
\text { institution with access to financial } \\
\text { transactions in a public place -- ATMs } \\
\text { per } 1,000 \mathrm{~km}^{2}\end{array}$ & $\begin{array}{l}\text { Captures geographic } \\
\text { penetration; Proxies } \\
\text { the physical outreach } \\
\text { dimension }\end{array}$ & \multirow{4}{*}{$\begin{array}{c}\text { Compiled from } \\
\text { Financial Access } \\
\text { Survey, } \\
\text { International } \\
\text { Monetary Fund and } \\
\text { World Development } \\
\text { Indicators, World } \\
\text { Bank. }\end{array}$} \\
\hline $\begin{array}{l}\text { Automated Teller } \\
\text { Machines (ATMs) } \\
\text { Per Capita } \\
\text { [Demographic } \\
\text { Penetration] }\end{array}$ & $\begin{array}{l}\text { Automated teller machines are } \\
\text { computerized telecommunications } \\
\text { devices that provide clients of a financial } \\
\text { institution with access to financial } \\
\text { transactions in a public place -- ATMs } \\
\text { per } 100,000 \text { adults. }\end{array}$ & $\begin{array}{l}\text { Captures } \\
\text { demographic } \\
\text { penetration; Proxies } \\
\text { physical outreach } \\
\text { dimension }\end{array}$ & \\
\hline $\begin{array}{l}\text { Deposit Accounts } \\
\text { per } 1000 \text { adults }\end{array}$ & $\begin{array}{l}\text { Depositors with commercial banks are } \\
\text { the reported number of deposit account } \\
\text { holders at commercial banks and other } \\
\text { resident banks functioning as } \\
\text { commercial banks that are resident } \\
\text { nonfinancial corporations (public and } \\
\text { private) and households. For many } \\
\text { countries data cover the total number of } \\
\text { deposit accounts due to lack of } \\
\text { information on account holders. The } \\
\text { major types of deposits are checking } \\
\text { accounts, savings accounts, and time } \\
\text { deposits. }\end{array}$ & $\begin{array}{l}\text { Captures the usage } \\
\text { dimension of financial } \\
\text { inclusion }\end{array}$ & \\
\hline $\begin{array}{l}\text { Bank Branches } \\
\text { per } 100,000 \\
\text { adults }\end{array}$ & $\begin{array}{l}\text { Commercial bank branches are retail } \\
\text { locations of resident commercial banks } \\
\text { and other resident banks that function } \\
\text { as commercial banks that provide } \\
\text { financial services to customers and are } \\
\text { physically separated from the main } \\
\text { office but not organized as legally } \\
\text { separated subsidiaries. }\end{array}$ & $\begin{array}{l}\text { Captures } \\
\text { demographic } \\
\text { outreach dimension }\end{array}$ & \\
\hline
\end{tabular}


Table 2: Determinants of Financial Inclusion: ATMs Per Capita

\begin{tabular}{|l|c|c|c|c|}
\hline & $(\mathbf{1})$ & $\mathbf{( 2 )}$ & $\mathbf{( 3 )}$ & (4) \\
\hline $\begin{array}{l}\text { Dep Var: ATMs Per } \\
\text { Capita }\end{array}$ & FE: No FBE & FE: With FBE & RE: No FBE & RE: With FBE \\
\hline & & & & \\
\hline GDP Per Capita & $0.0113^{* * *}$ & $0.00916^{* * *}$ & $0.00956^{* * *}$ & $0.00894^{* * *}$ \\
\hline & $(0.00225)$ & $(0.00184)$ & $(0.00233)$ & $(0.00213)$ \\
\hline $\begin{array}{l}\text { Creditor Information } \\
\text { Index }\end{array}$ & $5.332^{* * *}$ & $3.611^{* * *}$ & $5.339^{* * *}$ & $3.919^{* * *}$ \\
\hline & $(1.133)$ & $(0.993)$ & $(1.100)$ & $(0.901)$ \\
\hline Legal Rights & 1.912 & $2.350^{*}$ & $2.651^{* *}$ & $2.490^{* *}$ \\
\hline & $(1.415)$ & $(1.264)$ & $(1.243)$ & $(1.122)$ \\
\hline Surface area & $0.0410^{* *}$ & $0.0583^{* * *}$ & $2.10 \mathrm{e}-06^{* * *}$ & $2.18 \mathrm{e}-06^{* *}$ \\
\hline & $(0.0191)$ & $(0.0142)$ & $(7.13 \mathrm{e}-07)$ & $(9.34 \mathrm{e}-07)$ \\
\hline Overhead Cost & 0.900 & $-1.302^{* *}$ & 0.859 & $-1.321^{* * *}$ \\
\hline & $(1.605)$ & $(0.592)$ & $(1.509)$ & $(0.508)$ \\
\hline $\begin{array}{l}\text { Credit to Govt. } \\
\text { Enterprises }\end{array}$ & $1.169^{* * *}$ & $0.760^{* *}$ & $1.037^{* * *}$ & $0.718^{* * *}$ \\
\hline & $(0.339)$ & $(0.307)$ & $(0.266)$ & $(0.268)$ \\
\hline $\begin{array}{l}\text { Women Employed in } \\
\text { Non-Agriculture }\end{array}$ & 0.896 & 0.593 & 0.429 & 0.311 \\
\hline & $(1.368)$ & $(1.430)$ & $(0.434)$ & $(0.454)$ \\
\hline Concentration Index & $-24.29^{*}$ & $-20.61^{*}$ & -17.77 & $-20.30^{*}$ \\
\hline & $(12.56)$ & $(11.88)$ & $(12.21)$ & $(11.23)$ \\
\hline Foreign Bank Entry & & $\mathbf{0 . 2 1 7 * *}$ & & $\mathbf{0 . 1 3 1 * *}$ \\
\hline & & $(0.102)$ & & $(0.0892)$ \\
\hline Observations & 230 & 181 & 230 & 181 \\
\hline R-squared & 0.569 & 0.595 & 0.558 & 0.581 \\
\hline Number of countries & 40 & 38 & 40 & 38 \\
\hline Country Fixed Effects & $Y E S$ & $Y E S$ & $N O$ & $N O$ \\
\hline RE: Random Efects & & & & \\
\hline
\end{tabular}

RE: Random Effects; FE: Fixed Effects

Robust Standard Errors Clustered for Countries in Parentheses

${ }^{* * *} \mathrm{p}<0.01,{ }^{* *} \mathrm{p}<0.05,{ }^{*} \mathrm{p}<0.1$ 
Table 3: Foreign Bank Entry and Bank Concentration

\begin{tabular}{|l|c|c|}
\hline & (1) & (2) \\
\hline Dep Var: ATMs Per Capita & Fixed Effects & Random Effects \\
\hline GDP Per Capita & & $0.00915^{* * *}$ \\
\hline & $0.00932^{* * *}$ & $(0.00209)$ \\
\hline Creditor Information Index & $0.00179)$ & $4.069^{* * *}$ \\
\hline & $3.776^{* * *}$ & $(0.892)$ \\
\hline Legal Rights & $(0.972)$ & $2.311^{* *}$ \\
\hline Surface area & $2.124^{*}$ & $(1.062)$ \\
\hline & $(1.086)$ & $2.30 \mathrm{e}-06^{* *}$ \\
\hline Overhead Cost & $0.0602^{* * *}$ & $(9.69 \mathrm{e}-07)$ \\
\hline & $(0.0139)$ & $-1.303^{* * *}$ \\
\hline Credit to Govt. Enterprises & $-1.344^{* *}$ & $(0.476)$ \\
\hline & $(0.561)$ & $0.651^{* *}$ \\
\hline Women Employed in Non-Agriculture & $0.689^{* *}$ & $(0.261)$ \\
\hline & $(0.307)$ & 0.240 \\
\hline Concentration Index & 0.206 & $(0.457)$ \\
\hline & $(1.449)$ & $25.87^{*}$ \\
\hline Foreign Bank Entry & 28.92 & $(15.62)$ \\
\hline & $(21.51)$ & $\mathbf{0 . 3 6 6 ^ { * * * }}$ \\
\hline Foreign Bank Entry*Concentration & $\mathbf{0 . 4 5 3 * * *}$ & $(0.109)$ \\
\hline & $(0.119)$ & $\mathbf{0 . 9 3 0 * *}$ \\
\hline Observations & $\mathbf{- 0 . 9 7 9 * *}$ & $(0.256)$ \\
\hline$R$-squared & $(0.364)$ & 181 \\
\hline Number of countries & 181 & 38 \\
\hline Country Fixed Effects & 0.618 & $N O$ \\
\hline Robust Standard Errors Clustered & 38 & \\
\hline & $Y E S$ & \\
\hline
\end{tabular}

Robust Standard Errors Clustered for Countries in Parentheses

${ }^{* * *} \mathrm{p}<0.01,{ }^{* *} \mathrm{p}<0.05,{ }^{*} \mathrm{p}<0.1$ 
Table 4: Fixed Effects Estimates - Determinants of Financial Inclusion: ATMs with Time Dummies

\begin{tabular}{|c|c|c|c|}
\hline & (1) & $(2)$ & $(3)$ \\
\hline Dep Var: ATMs Per Capita & Baseline & (1) with FBE & (2) with FBE*Concentration \\
\hline \multirow[t]{2}{*}{ GDP Per Capita } & $0.0105^{* * *}$ & $0.00584^{* * *}$ & $0.00618^{* * *}$ \\
\hline & $(0.00216)$ & $(0.00173)$ & $(0.00179)$ \\
\hline \multirow{2}{*}{ Creditor Information Index } & $5.011^{* * *}$ & $2.475^{* * *}$ & $2.671^{* * *}$ \\
\hline & $(1.090)$ & $(0.832)$ & $(0.794)$ \\
\hline \multirow[t]{2}{*}{ Legal Rights } & 1.932 & $2.459^{*}$ & $2.286^{*}$ \\
\hline & $(1.428)$ & $(1.337)$ & $(1.192)$ \\
\hline \multirow[t]{2}{*}{ Surface area } & $0.0395^{* *}$ & $0.0545^{* * *}$ & $0.0561^{* * *}$ \\
\hline & $(0.0189)$ & $(0.0111)$ & $(0.0112)$ \\
\hline \multirow[t]{2}{*}{ Overhead Cost } & 1.124 & $-0.816^{*}$ & $-0.878^{*}$ \\
\hline & $(1.606)$ & $(0.460)$ & $(0.459)$ \\
\hline \multirow[t]{2}{*}{ Credit to Govt. Enterprises } & $1.165^{* * *}$ & $0.508^{*}$ & 0.472 \\
\hline & $(0.336)$ & $(0.287)$ & $(0.290)$ \\
\hline \multirow[t]{2}{*}{ Women Employed in Non-Agriculture } & 0.789 & -0.333 & -0.558 \\
\hline & $(1.323)$ & $(1.340)$ & $(1.341)$ \\
\hline \multirow[t]{2}{*}{ Concentration Index } & -20.22 & -14.63 & 21.45 \\
\hline & $(12.38)$ & $(10.93)$ & $(22.55)$ \\
\hline \multirow[t]{2}{*}{ GFC dummy } & $3.221^{* * *}$ & $7.709^{* * *}$ & $7.206^{* * *}$ \\
\hline & $(1.091)$ & $(2.018)$ & $(2.091)$ \\
\hline \multirow[t]{2}{*}{ Foreign Bank Entry } & & $0.164^{*}$ & $0.341^{* *}$ \\
\hline & & $(0.0940)$ & $(0.130)$ \\
\hline \multirow[t]{2}{*}{ Foreign Bank Entry*Concentration } & & & $-0.721^{*}$ \\
\hline & & & $(0.390)$ \\
\hline Observations & 230 & 181 & 181 \\
\hline$R$-squared & 0.581 & 0.668 & 0.680 \\
\hline Number of countries & 40 & 38 & 38 \\
\hline Country Fixed Effects & YES & YES & YES \\
\hline
\end{tabular}

Robust Standard Errors Clustered for Countries in Parentheses

${ }^{* * *} \mathrm{p}<0.01,{ }^{* *} \mathrm{p}<0.05,{ }^{*} \mathrm{p}<0.1$ 
Table 5: Fixed Effects Estimates - Alternative Indicators of Financial Inclusion: ATM Density

\begin{tabular}{|l|c|c|c|}
\hline & $(\mathbf{1})$ & $\mathbf{( 2 )}$ & (3) \\
\hline Dep Var: ATM Density & Baseline & (1) with FBE & (2) With FBE*Concentration \\
\hline GDP Per Capita & & & $0.00828^{* *}$ \\
\hline & $0.00852^{*}$ & $0.00809^{* *}$ & $(0.00318)$ \\
\hline Creditor Information Index & $(0.00422)$ & $(0.00319)$ & $2.387^{* * *}$ \\
\hline & $3.120^{* * *}$ & $2.116^{* * *}$ & $0.733)$ \\
\hline Legal Rights & $(1.080)$ & $(0.747)$ & 0.121 \\
\hline & 0.748 & 0.630 & $0.748)$ \\
\hline Surface area & $(1.267)$ & $(1.090)$ & $0.668^{* * *}$ \\
\hline & $0.769^{* * *}$ & $0.666^{* * *}$ & $(0.0164)$ \\
\hline Overhead Cost & $(0.0272)$ & $(0.0160)$ & -0.571 \\
\hline & -0.208 & -0.416 & $0.545)$ \\
\hline Credit to Govt. Enterprises & $(0.568)$ & $(0.625)$ & 0.388 \\
\hline & 0.485 & 0.458 & $0.279)$ \\
\hline Women Employed in Non-Agriculture & $(0.367)$ & $(0.283)$ & $(0.811)$ \\
\hline & 1.279 & 0.689 & $55.36^{* *}$ \\
\hline Concentration Index & $(1.032)$ & $0.868)$ & $(22.04)$ \\
\hline & 6.492 & -4.567 & $\mathbf{0 . 5 4 1 * * *}$ \\
\hline Foreign Bank Entry & $(14.87)$ & $(15.69)$ & $(0.118)$ \\
\hline & & $\mathbf{0 . 2 3 9 * *}$ & $\mathbf{- 1 . 0 9 9 ^ { * * * }}$ \\
\hline Foreign Bank Entry*Concentration & & $(0.110)$ & $(0.298)$ \\
\hline & & & 148 \\
\hline Observations & 195 & 148 & 0.844 \\
\hline R-squared & 0.807 & 0.833 & 37 \\
\hline Number of countries & 39 & 37 & $Y E S$ \\
\hline Country Fixed Effects & $Y E S$ & $Y E S$ & \\
\hline
\end{tabular}

Robust Standard Errors Clustered for Countries in Parentheses

${ }^{* * *} \mathrm{p}<0.01,{ }^{* *} \mathrm{p}<0.05,{ }^{*} \mathrm{p}<0.1$ 
Table 6: Fixed Effects Estimates - Alternative Indicators of Financial Inclusion: Bank Accounts

\begin{tabular}{|c|c|c|c|}
\hline & (1) & (2) & (3) \\
\hline Dep Var: Bank Accounts Per Capita & Baseline & (1) with FBE & (2) with FBE*Concentration \\
\hline \multirow[t]{2}{*}{ GDP Per Capita } & $0.150^{* * *}$ & $0.176^{* * *}$ & $0.180^{* * *}$ \\
\hline & $(0.0268)$ & $(0.0364)$ & $(0.0364)$ \\
\hline \multirow[t]{2}{*}{ Creditor Information Index } & $36.59 * * *$ & 11.62 & 14.20 \\
\hline & $(9.991)$ & $(12.81)$ & $(12.88)$ \\
\hline \multirow[t]{2}{*}{ Legal Rights } & -3.394 & -11.08 & -10.47 \\
\hline & $(19.69)$ & $(21.40)$ & $(21.26)$ \\
\hline \multirow[t]{2}{*}{ Surface area } & $-4.605^{* *}$ & $224.6^{*}$ & $229.1^{* *}$ \\
\hline & $(2.221)$ & $(112.6)$ & $(111.9)$ \\
\hline \multirow[t]{2}{*}{ Overhead Cost } & $-12.26^{*}$ & -9.633 & -10.88 \\
\hline & $(7.109)$ & $(7.826)$ & $(7.831)$ \\
\hline \multirow[t]{2}{*}{ Credit to Govt. Enterprises } & $14.80^{* * *}$ & $11.39^{*}$ & $11.52^{*}$ \\
\hline & $(5.184)$ & $(6.003)$ & $(5.964)$ \\
\hline \multirow[t]{2}{*}{$\begin{array}{l}\text { Women Employed in Non- } \\
\text { Agriculture }\end{array}$} & 17.08 & 11.82 & 9.320 \\
\hline & $(10.83)$ & $(12.62)$ & $(12.67)$ \\
\hline \multirow[t]{2}{*}{ Concentration Index } & -83.06 & -218.6 & 217.5 \\
\hline & $(158.5)$ & $(207.3)$ & $(389.0)$ \\
\hline \multirow[t]{2}{*}{ Foreign Bank Entry } & & $2.695^{*}$ & $5.059 * *$ \\
\hline & & $(1.535)$ & $(2.351)$ \\
\hline \multirow[t]{2}{*}{ Foreign Bank Entry*Concentration } & & & -10.46 \\
\hline & & & $(7.915)$ \\
\hline Observations & 112 & 85 & 85 \\
\hline$R$-squared & 0.467 & 0.461 & 0.478 \\
\hline Number of countries & 23 & 21 & 21 \\
\hline Country Fixed Effects & YES & YES & YES \\
\hline
\end{tabular}

Robust Standard Errors Clustered for Countries in Parentheses ${ }^{* * *} \mathrm{p}<0.01,{ }^{* *} \mathrm{p}<0.05,{ }^{*} \mathrm{p}<0.1$ 
Table 7: Fixed Effects Estimates - Alternative Indicators of Financial Inclusion: Bank Branches

\begin{tabular}{|l|c|c|c|}
\hline & $(\mathbf{1})$ & $\mathbf{( 2 )}$ & $\mathbf{( 3 )}$ \\
\hline Dep Var: Bank Branches & Baseline & (1) with FBE & (2) with FBE*Concentration \\
\hline GDP Per Capita & & & \\
\hline & $0.00195^{* *}$ & $0.00187^{* * *}$ & $0.00189^{* * *}$ \\
\hline Creditor Information Index & $(0.000779)$ & $(0.000648)$ & $(0.000631)$ \\
\hline Legal Rights & $0.671^{* *}$ & $0.756^{* *}$ & $0.759^{* *}$ \\
\hline & $(0.314)$ & $(0.283)$ & $(0.294)$ \\
\hline Surface area & $2.514^{*}$ & $2.315^{*}$ & $2.306^{*}$ \\
\hline & $(1.407)$ & $(1.221)$ & $(1.237)$ \\
\hline Overhead Cost & $-0.0137^{* *}$ & $-0.0129^{* *}$ & $-0.0129^{* *}$ \\
\hline & $(0.00603)$ & $(0.00483)$ & $(0.00485)$ \\
\hline Credit to Govt. Enterprises & -0.232 & -0.339 & -0.340 \\
\hline & $(0.163)$ & $(0.203)$ & $0.205)$ \\
\hline Women Employed in Non- & 0.0849 & $0.112^{*}$ & $0.112^{*}$ \\
Agriculture & $0.0790)$ & $(0.0639)$ & $(0.0648)$ \\
\hline & 0.365 & 0.351 & 0.342 \\
\hline Concentration Index & & & $(0.369)$ \\
\hline & $(0.473)$ & $(0.358)$ & -2.649 \\
\hline Foreign Bank Entry & -1.855 & -4.292 & $(4.033)$ \\
\hline & $(5.831)$ & $(6.062)$ & 0.0361 \\
\hline Foreign Bank & & $\mathbf{0 . 0 2 8 2}$ & $(0.0340)$ \\
\hline Entry*Concentration & & $(0.0281)$ & -0.0327 \\
\hline & & & $(0.141)$ \\
\hline Observations & & & 197 \\
\hline$R$-squared & 248 & 197 & 0.513 \\
\hline Number of countries & 0.394 & 0.512 & 41 \\
\hline Country Fixed Effects & 42 & 41 & YES \\
\hline YES & YES & \\
\hline
\end{tabular}

Robust Standard Errors Clustered for Countries in Parentheses

*** $\mathrm{p}<0.01,{ }^{* *} \mathrm{p}<0.05,{ }^{*} \mathrm{p}<0.1$ 
Table 8: Fixed Effects Estimates - Lagged Foreign Bank Entry and All Indicators of Financial Inclusion

\begin{tabular}{|c|c|c|c|c|}
\hline & (1) & $(2)$ & (3) & (4) \\
\hline Variables & ATMs Per Capita & ATM Density & Bank Accounts & Bank Branches \\
\hline \multirow[t]{2}{*}{ GDP Per Capita } & $0.0109 * * *$ & $0.00825^{*}$ & $0.125^{* * *}$ & $0.00253^{* *}$ \\
\hline & $(0.00241)$ & $(0.00440)$ & $(0.0428)$ & $(0.000989)$ \\
\hline \multirow[t]{2}{*}{ Creditor Information Index } & $4.806^{* * *}$ & $2.806^{* *}$ & 13.06 & 0.363 \\
\hline & $(1.232)$ & $(1.043)$ & (25.79) & $(0.389)$ \\
\hline \multirow[t]{2}{*}{ Legal Rights } & -0.203 & -0.498 & 9.099 & $3.075^{* *}$ \\
\hline & $(0.884)$ & $(0.833)$ & $(20.62)$ & $(1.156)$ \\
\hline \multirow[t]{2}{*}{ Surface area } & $0.0560^{* * *}$ & $0.778^{* * *}$ & $-4.017^{* * *}$ & $-0.0142^{* *}$ \\
\hline & $(0.0200)$ & $(0.0248)$ & $(1.137)$ & $(0.00661)$ \\
\hline \multirow[t]{2}{*}{ Overhead Cost } & 1.468 & 0.115 & -7.946 & $-0.171^{*}$ \\
\hline & $(1.964)$ & $(0.501)$ & $(7.416)$ & $(0.0928)$ \\
\hline \multirow[t]{2}{*}{ Credit to Govt. Enterprises } & $1.212^{* * *}$ & 0.345 & 9.304 & 0.0927 \\
\hline & $(0.389)$ & $(0.316)$ & $(6.081)$ & $(0.0724)$ \\
\hline \multirow[t]{2}{*}{$\begin{array}{l}\text { Women Employed in Non- } \\
\text { Agriculture }\end{array}$} & 0.758 & 1.202 & 21.15 & 0.443 \\
\hline & $(1.356)$ & $(1.020)$ & $(23.68)$ & $(0.581)$ \\
\hline \multirow[t]{2}{*}{ Concentration Index } & 4.004 & $66.43^{* *}$ & 243.1 & -4.283 \\
\hline & $(46.10)$ & $(25.39)$ & $(325.4)$ & $(4.739)$ \\
\hline \multirow[t]{2}{*}{ Lagged Foreign Bank Entry } & $0.397 *$ & $0.568 * * *$ & $5.656 * *$ & 0.0296 \\
\hline & $(0.229)$ & $(0.127)$ & $(2.783)$ & $(0.0409)$ \\
\hline \multirow[t]{2}{*}{$\begin{array}{l}\text { Lagged Foreign Bank } \\
\text { Entry*Concentration }\end{array}$} & -0.585 & $-1.026^{* * *}$ & $-10.27^{*}$ & 0.0730 \\
\hline & $(0.620)$ & $(0.312)$ & $(7.460)$ & $(0.120)$ \\
\hline Observations & 186 & 181 & 89 & 197 \\
\hline$R$-squared & 0.574 & 0.826 & 0.422 & 0.383 \\
\hline Number of countries & 39 & 38 & 21 & 40 \\
\hline Country Fixed Effects & $Y E S$ & $Y E S$ & $Y E S$ & $Y E S$ \\
\hline
\end{tabular}

Robust Standard Errors Clustered for Countries in Parentheses *** $\mathrm{p}<0.01, * * \mathrm{p}<0.05, * \mathrm{p}<0.1$ 


\section{Annex Table A1: Full Sample - List of Countries and Regions}

\begin{tabular}{|l|l|}
\hline Region & Country \\
\hline East Asia and Pacific (EAP) & Indonesia, Korea, Malaysia, Philippines, Thailand \\
\hline Europe and Central Asia (ECA) & $\begin{array}{l}\text { Armenia, Bulgaria, Croatia, Czech Republic, Estonia, } \\
\text { Georgia, Kyrgyz Republic, Latvia, Lithuania, Moldova, } \\
\text { Romania, Russia, Serbia, Slovak Republic, Slovenia, } \\
\text { Ukraine. }\end{array}$ \\
\hline Latin America and Caribbean (LAC) & $\begin{array}{l}\text { Antigua, Argentina, Bolivia, Brazil, Chile, Colombia, } \\
\text { Dominican Republic, Guatemala, Jamaica, Mexico, } \\
\text { Panama, Paraguay, Peru, Uruguay, Venezuela }\end{array}$ \\
\hline Middle East and North Africa (MENA) & $\begin{array}{l}\text { Algeria, Bahrain, Jordan, Kuwait, Libya, Morocco and } \\
\text { Oman }\end{array}$ \\
\hline South Asia (SA) & India, Pakistan and Sri Lanka \\
\hline Sub Saharan Africa (SSA) & $\begin{array}{l}\text { Madagascar, Mali, Mauritius, Mozambique, Namibia, } \\
\text { Niger, Rwanda, Senegal, South Africa, Togo, } \\
\text { Zimbabwe }\end{array}$ \\
\hline
\end{tabular}




\section{Annex Table A2: Sources and Definitions}

\begin{tabular}{|c|c|c|}
\hline Variable & Definition & Source \\
\hline $\begin{array}{l}\text { Foreign Bank Assets } \\
(\%)\end{array}$ & $\begin{array}{l}\text { Share of foreign bank assets in total banking } \\
\text { assets }\end{array}$ & $\begin{array}{l}\text { Claessens and Neeltje van Horen } \\
\text { (2011); Claessens, et al. (2008) }\end{array}$ \\
\hline $\begin{array}{l}\text { GDP Per Capita } \\
\text { (Constant } 2000 \\
\text { USD) }\end{array}$ & GDP Per Capita measured in 2000 US dollars & $\begin{array}{l}\text { Global Financial Development } \\
\text { Database - World Bank }\end{array}$ \\
\hline $\begin{array}{l}\text { Creditor } \\
\text { Information }\end{array}$ & $\begin{array}{l}\text { This index measures rules and practices } \\
\text { affecting the coverage, scope and accessibility } \\
\text { of credit information available through either } \\
\text { a public credit registry or a private credit } \\
\text { bureau. ( } 0 \text { =low to } 6=\text { high) }\end{array}$ & $\begin{array}{l}\text { Doing Business Database - World } \\
\text { Bank }\end{array}$ \\
\hline Legal Rights & $\begin{array}{l}\text { This index measures the degree to which } \\
\text { collateral and bankruptcy laws protect the } \\
\text { rights of borrowers and lenders and thus } \\
\text { facilitate lending. }\end{array}$ & $\begin{array}{l}\text { World Development Indicators - } \\
\text { World Bank }\end{array}$ \\
\hline $\begin{array}{l}\text { Automated Teller } \\
\text { Machines (ATMs) } \\
\text { (per } 100,000 \\
\text { adults) }\end{array}$ & $\begin{array}{l}\text { Automated teller machines are computerized } \\
\text { telecommunications devices that provide } \\
\text { clients of a financial institution with access to } \\
\text { financial transactions in a public place. }\end{array}$ & $\begin{array}{l}\text { Financial Access Survey - } \\
\text { International Monetary Fund }\end{array}$ \\
\hline ATM Density & ATMs per $1,000 \mathrm{~km} 2$ & $\begin{array}{l}\text { Financial Access Survey - } \\
\text { International Monetary Fund }\end{array}$ \\
\hline $\begin{array}{l}\text { Bank Accounts per } \\
1000 \text { adults } \\
\text { (commercial banks- } \\
\text { bank survey) }\end{array}$ & $\begin{array}{l}\text { Number of depositors with commercial } \\
\text { banks per } 1,000 \text { adults. }\end{array}$ & $\begin{array}{l}\text { Financial Access Survey - } \\
\text { International Monetary Fund }\end{array}$ \\
\hline $\begin{array}{l}\text { Bank Branches per } \\
100,000 \text { adults } \\
\text { (commercial banks) }\end{array}$ & $\begin{array}{l}\text { Number of commercial bank branches per } \\
100,000 \text { adults. }\end{array}$ & $\begin{array}{l}\text { Financial Access Survey - } \\
\text { International Monetary Fund }\end{array}$ \\
\hline $\begin{array}{l}\text { Banking } \\
\text { Concentration } \\
\text { (Lerner Index) }\end{array}$ & $\begin{array}{l}\text { A measure of market power in the banking } \\
\text { market. It compares output pricing and } \\
\text { marginal costs (that is, markup). An increase } \\
\text { in the Lerner index indicates a deterioration } \\
\text { of the competitive conduct of financial } \\
\text { intermediaries. (Bankscope) }\end{array}$ & $\begin{array}{l}\text { Global Financial Development } \\
\text { Database - World Bank }\end{array}$ \\
\hline $\begin{array}{l}\text { Surface Area (sq. } \\
\text { km) }\end{array}$ & $\begin{array}{l}\text { Surface area is a country's total area, } \\
\text { including areas under inland bodies of water } \\
\text { and some coastal waterways. }\end{array}$ & $\begin{array}{l}\text { World Development Indicators } \\
\text { Database - World Bank }\end{array}$ \\
\hline $\begin{array}{l}\text { Overhead Costs to } \\
\text { Total Assets (\%) }\end{array}$ & $\begin{array}{l}\text { Operating expenses of a bank as a share of } \\
\text { the value of all held assets. Total assets } \\
\text { include total earning assets, cash and due } \\
\text { from banks, foreclosed real estate, fixed } \\
\text { assets, goodwill, other intangibles, current } \\
\text { tax assets, deferred tax, discontinued } \\
\text { operations and other assets. (Bankscope) }\end{array}$ & $\begin{array}{l}\text { Global Financial Development } \\
\text { Database - World Bank }\end{array}$ \\
\hline $\begin{array}{l}\text { Credit to } \\
\text { Government and } \\
\text { State-Owned } \\
\text { Enterprises to GDP } \\
(\%)\end{array}$ & $\begin{array}{l}\text { Ratio between credit by domestic money } \\
\text { banks to the government and state-owned } \\
\text { enterprises and GDP. (International } \\
\text { Monetary Fund, International Financial } \\
\text { Statistics) }\end{array}$ & $\begin{array}{l}\text { Global Financial Development } \\
\text { Database - World Bank }\end{array}$ \\
\hline
\end{tabular}


Annex Table A3: Hausman Test Results

\begin{tabular}{|l|c|c|c|c|}
\hline & $\mathbf{( b )}$ & $\mathbf{( B )}$ & $\mathbf{( b - B )}$ & Sqrt (diag(V_b-V_B) \\
\hline Variables & Fixed & Random & Difference & S.E. \\
\hline & 0.0091596 & 0.0089425 & 0.0002171 & 0.0012482 \\
\hline GDP Per Capita & 3.611058 & 3.919179 & -0.3081211 & 0.2554629 \\
\hline Creditor Information Index & 2.349598 & 2.489798 & -0.1402004 & 0.4591073 \\
\hline Legal Rights & 0.058285 & $2.18 \mathrm{e}-06$ & 0.0582828 & 0.0312958 \\
\hline Surface area & -1.301727 & -1.320912 & 0.0191858 & 0.143953 \\
\hline Overhead Cost & 0.7604603 & 0.7184529 & 0.0420074 & 0.1404426 \\
\hline Credit to Govt. Enterprises & 0.5929221 & 0.3114816 & 0.2814404 & 0.5398079 \\
\hline $\begin{array}{l}\text { Women Employed in Non- } \\
\text { Agriculture }\end{array}$ & -20.61223 & -20.30291 & -0.30932 & 3.002499 \\
\hline Concentration Index & & & & 0.0461553 \\
\hline
\end{tabular}

$\mathrm{b}=$ consistent under Ho and $\mathrm{Ha}$;

$\mathrm{B}=$ inconsistent under $\mathrm{Ha}$, efficient under Ho;

Test: Ho: Difference in coefficients not systematic

Chi2(9) =(b-B) $\left[\left(V_{-} b-V_{-} B\right)^{\wedge}(-1)\right](b-B)$

Prob $>$ Chi2 $=0.3603$ 
Annex Table A4: Fixed Effects Estimates - Determinants of Financial Inclusion: ATMs

\begin{tabular}{|c|c|c|}
\hline & (1) & (2) \\
\hline Variables & ATMs Per Capita & ATM Density \\
\hline \multirow{2}{*}{ GDP Per Capita } & $0.00609 * *$ & $0.00809 *$ \\
\hline & $(0.00243)$ & $(0.00422)$ \\
\hline \multirow[t]{2}{*}{ Creditor Information Index } & $2.898^{* * *}$ & $2.170^{* *}$ \\
\hline & $(0.834)$ & $(0.963)$ \\
\hline \multirow[t]{2}{*}{ Legal Rights } & $2.494^{* *}$ & 0.336 \\
\hline & $(1.119)$ & $(1.017)$ \\
\hline \multirow{2}{*}{ Surface area } & $0.0623^{* * *}$ & $0.664^{* * *}$ \\
\hline & $(0.0135)$ & $(0.0173)$ \\
\hline \multirow[t]{2}{*}{ Overhead Cost } & $-0.755^{* *}$ & -0.410 \\
\hline & $(0.325)$ & $(0.622)$ \\
\hline \multirow[t]{2}{*}{ Credit to Govt. Enterprises } & 0.426 & 0.355 \\
\hline & $(0.331)$ & $(0.306)$ \\
\hline \multirow[t]{2}{*}{$\begin{array}{l}\text { Women Employed in Non- } \\
\text { Agriculture }\end{array}$} & 0.452 & 0.547 \\
\hline & $(1.066)$ & $(0.652)$ \\
\hline \multirow[t]{2}{*}{ Concentration Index } & 7.304 & $49.46^{*}$ \\
\hline & $(15.86)$ & $(26.09)$ \\
\hline \multirow[t]{2}{*}{ Credit-to-GDP } & $0.290^{* *}$ & 0.0569 \\
\hline & $(0.127)$ & $(0.151)$ \\
\hline \multirow[t]{2}{*}{ Foreign Bank Entry } & $0.270^{* *}$ & $0.492^{* * *}$ \\
\hline & $(0.111)$ & $(0.135)$ \\
\hline \multirow[t]{2}{*}{ Foreign Bank Entry*Concentration } & -0.502 & $-1.002^{* *}$ \\
\hline & $(0.343)$ & $(0.397)$ \\
\hline Observations & 169 & 137 \\
\hline$R$-squared & 0.668 & 0.851 \\
\hline Number of countries & 36 & 35 \\
\hline Country Fixed Effects & YES & YES \\
\hline
\end{tabular}

Robust Standard Errors Clustered for Countries in Parentheses ${ }^{* * *} \mathrm{p}<0.01,{ }^{* *} \mathrm{p}<0.05,{ }^{*} \mathrm{p}<0.1$ 